\title{
Fusarium sp. L-Asparaginases: purification, characterization and potential assessment as anti- leukemic chemotherapeutic agent
}

Sulaiman A. Al Yousef ( $\nabla$ sulaimanalyousef07@gmail.com )

Hafr Al Batin University

\section{Research Article}

Keywords: Fusarium sp., asparaginase, anti-leukemic, chemotherapy, cytotoxicity

Posted Date: April 15th, 2021

DOI: https://doi.org/10.21203/rs.3.rs-305549/v1

License: (c) (i) This work is licensed under a Creative Commons Attribution 4.0 International License.

Read Full License 


\section{Abstract}

Asparaginases play an important role in the treatment of leukemia. It is part of chemotherapy in the treatment of leukemia in the last three decades. L-Asparaginase isolated from Fusarium sp. isolated from soil and purified using ammonium sulfate precipitation and Sephadex G 100. Characterization of the crude enzyme revealed it is a metalloprotease inhibited by EDTA. $\mathrm{Hg}^{+}, \mathrm{Cd}^{+}$, and $\mathrm{Pb}^{+}$also inhibited the enzyme. $\mathrm{Mg}^{+}, \mathrm{Zn} 2^{+}$and $\mathrm{Ca}_{2}{ }^{+}$activated $\mathrm{L}$. asparaginase. Further, the kinetic studies of purified enzyme were carried out. $\mathrm{V}_{\max }$ and $\mathrm{K}_{\mathrm{m}}$ and were $0.031 \mathrm{M}$ and $454 \mathrm{U} / \mathrm{mL}$, respectively. The optimum temperature was $30^{\circ} \mathrm{C}$, optimum pH was 7 . Concerning substrate specificity; gelatin and casein in addition to Lasparagine were tested. The enzyme was found to be non-specific, could hydrolyze all tested substrates at different rates. Maximum enzyme activity was recorded in the case of L-asparagine, followed by Casein and gelatin, respectively. The molecular weight of L-Asparaginase was $22.5 \mathrm{kDa}$. The Antileukemic cytotoxicity assay of the enzyme against RAW2674 leukemic cell lines by MTT viability test was estimated. The enzyme exhibited anti-leukemic activity with $\mathrm{IC}_{50}$ of $70 \mathrm{Uml}^{-1}$ and relative viability $70 \%$ of control. The current work presents additional information regarding the purification and characterization of the enzyme produced by Fusarium $s p$. and its evaluation as a potential anti-leukemic chemotherapeutic agent.

\section{Introduction}

L-Asparaginase is a metabolism-targeted anti-neoplastic agent help in the treatment of leukemia. This is due to the enzymatic breakdown of glutamine and asparagine, which is changed in the blood to glutamic acid and aspartic acid, respectively (Covini et al. 2012; Lopes et al. 2017). L-Asparaginase converts Lasparagine to aspartic acid and ammonia. It is used in chemotherapy to treat leukemia and lymphomas (El-Nagga et al., 2014). L-Asparaginase is found in animals, plants, microorganisms. It is used as a chemotherapeutic agent to treat lymphoma and lymphoproliferative disorders (Cachumba et al., 2016).

L-Asparaginase is an amid hydrolase enzyme that deamidates L-asparagine to L-aspartic acid and ammonia and L-glutamine to L-glutamic acid and ammonia. The enzyme can hydrolyze asparagine, causing the death of tumor cells, which lack asparagine synthetases. (Costa et al., 2016). It hydrolyses Lasparagine to ammonia and aspartic acid. The mechanism of the enzyme is due to the hydrolysis of Lasparagine, where tumor cells cannot form asparagine and are killed. This leads to susceptibility to the cytotoxicity of L-Asparaginase due to inhibition in protein synthesis (El-Nagga et al., 2014).

Many factors affect the L-asparaginase therapeutic properties, including L-asparaginase sources, upstream and downstream bioprocessing, tumor cell resistance, anti-asparaginase antibiotics, and hydrolysis rate. $\mathrm{Km}$ (Michaelis constant), clearance of the serum, pharmacological aspects, and hepatic asparagine de novo biosynthesis (Lopes et al. 2017). Enzyme biological production involves multiple catalytic reactions, which make it a sophisticated process. Several parameters have to be taken into account for selecting a commercially viable source of L-asparaginase, such as environmental conditions, biochemical parameters, and genetic influence(Cachumba et al., 2016). 
Since it was first recorded in E. coli, microorganisms have become the most abundant source of LAsparaginase (Mashburn and Wriston 1964). Microbes generate distinct asparaginase types that vary in their cellular locations and features, namely (periplasmic, extracellular, intracellular, and glutaminase asparaginase) that have a role to play in fundamental metabolism (Orabi et al. 2019b). including bacteria and fungi: Erwinia caratovora (Pieters et al. 2011), Escherichia coli (Duval et al. 2002) Aspergillus niger (Luhana et al. 2013),Aspergillus nidulans, Aspergillus tamari and Aspergillus terreus, (Sarquis et al. 2004a), Penicillium sp. (M.Sc et al. 2012) Helminthosporium, Paecilomyces, Alternaria and Cladobotrytis (Gupta et al. 2009).

L-asparaginase from the terrestrial and marine environments has been reported from both gram-positive and gram-negative bacteria. Gram-positive bacteria were less investigated than Gram-negative bacteria(Ameen et al., 2021). L Asparaginase can be classified into two main types, type I and type II asparaginase, in most gram-negative bacteria. Type I L-asparaginase is quantitatively expressed and has both L-glutamine and L-asparagine amino acid enzymatic activity. In comparison, L-asparaginase Type II has high specific L-asparagine activity and is only induced in an anaerobic state(Batool et al., 2016; Orabi et al., 2019a).

Apart from its medical usage, L-Asparaginase were also categorized as inhibitors of acrylamide formation in heated foods (Kornbrust et al. 2009); the International Agency for Research on Cancer) declared acrylamide as a potent neurotoxin and a carcinogen Implying that L-Asparaginases have future potential in the food industries (Kornbrust et al. 2009).

This enzyme's importance can also be seen from its high global demand of $\$ 380$ million in 2017, which is expected to increase by $\$ 420$ million by 2025 (Alam et al., 2019). The present work's main objective was to assay L-Asparaginases extracted from soil Fusarium species and optimize the growth parameters to achieve maximum enzyme production, purification, characterization of the enzyme, and assess its antileukemic bioactivity.

\section{Material And Methods}

\section{Fungal Isolation}

Ten soil samples were collected from the soil's garden, college of Applied Medical Science, Hafr Al Batin University, Hafr Al-Batin, Saudi Arabia. One gram of each soil sample was added into $9 \mathrm{ml}$ of sterile distilled water, serially diluted $\left(10^{-2}\right.$ and $\left.10^{-3}\right)$, and $0.2 \mathrm{~mL}$ was plated into Potato Dextrose Agar (PDA) and incubated at $28^{\circ} \mathrm{C}$ for $96 \mathrm{~h}$ (Taubeneck 2007).

\section{Identification of fungi}

Fungal colonies were purified and identified (Taubeneck 2007). Eventually, fungal species were transferred to PDA slants, incubated at $28^{\circ} \mathrm{C}$ for 4 days, and stored at $4^{\circ} \mathrm{C}$, until use. 


\section{Culture media and growth conditions}

The culture medium used for the study was a modified Czapek-Dox medium containing $\mathrm{g} / \mathrm{l}$ of, Glucose, 2.0; L-asparagine, $10.0 ; \mathrm{KH}_{2} \mathrm{PO}_{4}, 1.52 ; \mathrm{KCl}, 0.52 ; \mathrm{MgSO}_{4} .7 \mathrm{H}_{2} \mathrm{O}, 0.52 ; \mathrm{CuNO}_{3} .3 \mathrm{H}_{2} \mathrm{O}$, trace; $\mathrm{ZnSO}_{4} .7 \mathrm{H}_{2} \mathrm{O}$, trace; $\mathrm{FeSO}_{4} \cdot 7 \mathrm{H}_{2} \mathrm{O}$, trace; Agar, 18.0, initial pH 5.6 supplemented with either bromo cresol purple or phenol red dyes both at $0.009 \%$ (Saxena and Sinha, 1981). The cultures were incubated at $28^{\circ} \mathrm{C}$ under shaken conditions (120 rpm) for 4 days.

\section{L-Asparaginase induction}

L-Asparaginase induction was performed in $250 \mathrm{~mL}$ flasks with $50 \mathrm{~mL}$ medium. Inoculate the medium with Fusarium sp. Incubate flasks in shaking incubator $(150 \mathrm{rpm})$ for $48 \mathrm{~h}$ at $37^{\circ} \mathrm{C}$ Whatman No. 1 harvested cultures. Nesslerization was used to assay L-Asparaginase activity(IMADA et al., 2009).

\section{L-Asparaginase quantitative assay}

The enzyme $(0.5 \mathrm{~mL})$ was added in reaction mixture with $0.04 \mathrm{M} \mathrm{L}$-asparagine $(0.5 \mathrm{~mL}), 0.5 \mathrm{M}$ phosphate-buffer $(0.5 \mathrm{~mL}$ ), and distilled water (up to $2.0 \mathrm{~mL}$ ). The mixture was incubated for $30 \mathrm{~min}$ at $37^{\circ} \mathrm{C}$. The reaction was stopped by adding $1.5 \mathrm{M}$-trichloroacetic acid $(0.5 \mathrm{~mL}) .0 .2 \mathrm{ml}$ of Nessler's reagent and $0.1 \mathrm{ml}$ of the reaction mixtures were added to $3.7 \mathrm{ml}$ of distilled water. After $20 \mathrm{~min}$ at $20^{\circ} \mathrm{C}$, the absorbance was measured at $450 \mathrm{~nm}$ was measured. Ammonia released was determined. One unit of LAsparaginase was defined as the amount of enzyme which catalyzes the production of $1 \mathrm{mmol}$ of ammonia per min under the standard conditions of the assay (IMADA et al. 2009)

\section{Enzyme purification}

Two purification steps were carried out to purify L-Asparaginase, $\left(\mathrm{NH}_{4}\right)_{2} \mathrm{SO}_{4}$ precipitation up to $80 \%$, gel filtration through three Sephadex columns (G 100) with elution by $0.01 \mathrm{M}$ phosphate buffer pH 8 .

\section{Determination of protein}

The protein was measured using Lowry et al. (1951). A sample of $0.5 \mathrm{~mL}$ was mixed with $1 \mathrm{~mL}$ freshly mixed $1: 1$ ratio solution of $2 \%$ sodium hydroxide and $0.5 \%$ copper sulphate in $1 \%$ sodium tartrate. The mixture was left for 10 minutes before the addition of $0.1 \mathrm{~mL}$ folin phenol reagent and made up to a volume. The optical density of the mixture was measured after 30 minutes at $700 \mathrm{~nm}$.

\section{Molecular mass determination}

Molecular mass was determined using SDS-PAGE with coomassie brilliant blue staining method (LAEMMLI 1970).

\section{Characterization of enzyme}


Effect of temperature on L-Asparaginase production was assayed at different temperatures $\left(10-60^{\circ} \mathrm{C}\right)$ in $50 \mathrm{mM}$ phosphate buffer ( $\mathrm{pH}$ 7.0). The flasks were incubated for 4 days, and the supernatant was used as a crude enzyme to calculate the L-Asparaginase activity.

\section{Thermal Stability}

L-Asparaginase was incubated at $10-70^{\circ} \mathrm{C}$ for an hour, and then an assay was carried out to determine the remained activity.

\section{Effect of pH}

The enzyme activity at $37^{\circ} \mathrm{C}$ was assayed at pH values $3-10$, using different buffers ( $50 \mathrm{mM}$ acetate $\mathrm{pH}$ 3.0-5.0, $50 \mathrm{mM}$ phosphate $\mathrm{pH}$ 6.0-8.0, and $50 \mathrm{mM}$ carbonate buffer $\mathrm{pH}$ 9.0-10. Incubation time 4 days.

\section{Effect of metal ions}

L-Asparaginase was pre-incubated with metal ions (1 mM), including Zn SO4 $, \mathrm{Mg} \mathrm{Cl}_{2}, \mathrm{Hg} \mathrm{Cl}_{2}, \mathrm{Cd} \mathrm{Cl}_{2}, \mathrm{~Pb}$ acetate, and $\mathrm{Ca}_{2}$ at $40^{\circ} \mathrm{C}$ for 20 min. After incubation, the residual activity was measured (Wang et al., 2012).

\section{Substrate concentration}

Different L-asparagine concentrations $(0-0.1 \mathrm{M})$ were used. The reaction mixture was incubated at optimum temperature for the enzyme, and then the enzyme activity was measured.

\section{Determination of $\mathrm{Km}$ and Vmax}

By using different concentrations $(0-0.12 \mathrm{M})$ of $L$-asparagine. The reaction mixture was incubated at optimum temperature for $1 \mathrm{~h}$, and then the enzyme activity was measured using the standard assay procedure.

\section{Substrate specificity}

Enzyme activity was determined using various substrates: gelatin, casein in addition to L-asparagine. The incubation temperature was $37^{\circ} \mathrm{C}$ for $60 \mathrm{~min}$.

\section{Cytotoxicity assay of L-Asparaginase against RAW2674 leukemic cell line}

RAW2674 leukemic $\left(0.5 \times 10^{5}\right.$ cells/ well $)$ in media free of serum were added to 96 -well microplate flat bottom, and $20 \mu \mathrm{l}$ of different enzyme concentrations were added incubated at $37^{\circ} \mathrm{C}$ for $24 \mathrm{~h}$. Then media were removed, and 3-4, 5-dimethylthiazole -2-yl-2, 5-diphenyltetrazolium bromide (MTT $40 \mu \mathrm{l}$ ) were added and incubated for $4 \mathrm{~h}$. $180 \mu \mathrm{l}$ of acidified isopropanol/well was added to MTT crystals, solubilize it, and the plate was shacked at room temperature. 
Absorbance was determined at $570 \mathrm{~nm}$ using 96 wells microplate ELISA reader. Triplicate repeats were performed for each enzyme concentration, and the average was calculated. Relative viability: Absorbance of treated cells / Absorbance of control untreated cells $\times 100$.

\section{Results}

\section{Fusarium L-asparaginase two-step purification}

Various methods are used for producing and optimizing $L$ Asparaginase from various microorganisms. Conditions of reaction for enzyme production vary from one organism to another and maybe produced in or after induction. Two purification steps were carried out to purify L-Asparaginase, $\left(\mathrm{NH}_{4}\right)_{2}$ $\mathrm{SO}_{4}$ precipitation up to $80 \%$, gel filtration through three Sephadex columns (G 100) with elution by $0.01 \mathrm{M}$ phosphate buffer $\mathrm{pH} 8$.

In the crude enzyme activity, the activity was $340 \mathrm{U} / \mathrm{ml}$, protein concentration was $100 \mathrm{mg} / \mathrm{ml}$, and specific activity was $3.4 \mathrm{U} / \mathrm{mg}$. The recovery was $100 \%$. In case of $\left(\mathrm{NH}_{4}\right)_{2} \mathrm{SO}_{4}$, the activity was $177 \mathrm{U} / \mathrm{ml}$, protein concentration was $46 \mathrm{mg} / \mathrm{ml}$, and specific activity was $3.84 \mathrm{U} / \mathrm{mg}$. The recovery was $52.06 \%$, with a purification fold of 1.13 of the crude enzyme. In Sephadex G100; the activity was $145 \mathrm{U} / \mathrm{ml}$, protein concentration was $6 \mathrm{mg} / \mathrm{ml}$, and specific activity was $24.2 \mathrm{U} / \mathrm{mg}$. The recovery was $42.65 \%$, with a purification fold of 6.30 of the crude enzyme. The two purification steps finally resulted in the appearance of one peak of activity (Table 1 ).

Table 1

Fusarium sp. L-Asparaginase Purification steps

\begin{tabular}{cccccc}
\hline $\begin{array}{c}\text { Purification } \\
\text { procedure }\end{array}$ & $\begin{array}{c}\text { L-Asparaginase activity } \\
(\mathrm{U} / \mathrm{ml})\end{array}$ & $\begin{array}{c}\text { Protein } \\
(\mathrm{mg} / \mathrm{ml})\end{array}$ & $\begin{array}{c}\text { Specific } \\
\text { activity } \\
(\mathrm{U} / \mathrm{mg})\end{array}$ & $\begin{array}{c}\text { Purification fold } \\
\text { crude }\end{array}$ & $\begin{array}{c}\text { Recovery } \\
(\%)\end{array}$ \\
\hline Crude & 340 & 100 & 3.40 & - & 100 \\
$\left(\mathrm{NH}_{4}\right)_{2} \mathrm{SO}_{4}$ & 177 & 46 & 3.84 & 1.13 & 52.06 \\
Sephadex & 145 & 6 & 24.2 & 6.30 & 42.65 \\
$\mathrm{G} 100$ & & & & & \\
\hline
\end{tabular}

\section{Molecular mass Determination of I-asparaginase}

Molecular weight determination using SDS-PAGE revealed the presence of a single protein band. This indicated the complete homogeneity of the enzyme. The molecular mass was $22.5 \mathrm{kDa}$.

\section{Characterization of the L-Asparaginase}

\section{Effect of temperature}


The biochemical properties of L-Asparaginases from different organisms differ. Commonly, the optimal temperature is between $30^{\circ} \mathrm{C}$ and $40^{\circ} \mathrm{C}$ for L-asparaginase activity. From the graph, it is clear that as the temperature increases, the enzyme activity increases. The optimum temperature of L-Asparaginase was $30^{\circ} \mathrm{C}$. Higher temperatures caused a decrease in enzyme activity, where the activity was lost entirely at a temperature from $50-60^{\circ} \mathrm{C}$ (Fig.2).

\section{Thermal stability}

From the data in Table 2, it is clear that the enzyme activity at temperature $10^{\circ} \mathrm{C}$ was $180 \mathrm{U} / \mathrm{mL}$ while the residual activity recorded $81.8 \%$. Temperature $20^{\circ} \mathrm{C}$ recorded enzyme activity $220 \mathrm{U} / \mathrm{mL}$ representing 100 $\%$ residual activity. An increase in temperature was accompanied by a decrease in both enzymatic activity and residual activity as well.

\section{Table 2}

Thermal stability of L-Asparaginase purified from Fusarium sp.

\begin{tabular}{|c|c|c|c|}
\hline $\begin{array}{c}\text { Temperature } \\
\text { (C) }\end{array}$ & Activity of L-Asparaginase & $(\mathrm{U} / \mathrm{mL})$ & Residual Activity (\%) \\
\hline 10 & 180 & & 81.8 \\
\hline 20 & 220 & & 100 \\
\hline 30 & 150 & & 68.2 \\
\hline 37 & 130 & & 59.1 \\
\hline 40 & 120 & & 54.5 \\
\hline 50 & 70 & & 31.8 \\
\hline 60 & 30 & & 13.6 \\
\hline 70 & 0 & & 0 \\
\hline
\end{tabular}

\section{Substrate concentration}

The data in Table 3 shows that as the substrate concentration increases, the enzymatic activity increases to reach maximum $(300 \mathrm{U} / \mathrm{mL})$ at 0.06 and $0.08 \mathrm{M}$ substrate concentration. Higher concentration $(0.1 \mathrm{M})$ caused a decrease in enzyme activity.

TABLE 3

Effect of different L-asparagine concentrations on enzyme activity of Fusarium sp.

\begin{tabular}{ccc}
\hline $\begin{array}{c}\text { Concentration of L- } \\
\text { asparagine }(\mathrm{M})\end{array}$ & $\begin{array}{c}\text { Activity of L- asparaginase } \\
/ \mathrm{mL})\end{array}$ & $\begin{array}{c}\text { (U } \\
\text { percent of max } \\
\text { activity }\end{array}$ \\
\hline 0.00 & 000 & 00.0 \\
0.02 & 180 & 60.0 \\
0.04 & 260 & 86.6 \\
0.06 & 300 & 100 \\
0.08 & 300 & 100 \\
0.10 & 200 & 66.6 \\
\hline
\end{tabular}

$\mathrm{PH}$

Almost all the isolated and purified L-Asparaginases from microbial sources operate in a basic medium with an 8.0 to $10 \mathrm{PH}$. It is clear that as $\mathrm{pH}$ increases, the enzyme activity increases up to $\mathrm{pH}$, where the 
optimum $\mathrm{pH}$ of L- asparaginase extracted from Fusarium sp. was detected. An increase in $\mathrm{pH}$ value caused a dramatic decrease in enzyme activity( Fig. 3)

\section{Metal ions}

Different ions influence L-asparaginase activity in various ways. L-Asparaginase extracted from Fusarium sp. was completely inhibited by EDTA, $\mathrm{Hg}^{2+}, \mathrm{Cd}^{2+}$, and $\mathrm{Pb}^{2+} . \mathrm{Zn}^{2+}, \mathrm{Mg}^{2+}$, and $\mathrm{Ca}^{2+}$ activated the enzyme. Maximum activation was detected in the case of $\mathrm{Mg}^{2+}$, followed by $\mathrm{Zn}^{2+}$ and $\mathrm{Ca}^{2+}$ (Fig. 4).

\section{Substrate specificity}

With respect to substrate specificity, the experiment was carried out using gelatin and casein in addition to L-asparagine. The enzyme was found to be non-specific, could hydrolyze all tested substrates at different rates. Maximum enzyme activity was recorded in the case of L-asparagine, followed by Casein and gelatin, respectively.

\section{$\mathrm{K}_{\mathrm{m}}$ and $\mathrm{V}_{\max }$ of L-asparginase}

Knowledge of the kinetic parameters of the enzyme is necessary to understand the rate and specificity of most biological processes. Michaelis constant calculates the affinity of the substrate hydrolysis to the enzyme $(\mathrm{Km})$. Whereas $\mathrm{Vmax}$ is the limit at which a substrate concentration of an enzyme is completely saturated. A-line weaver bulk analysis showed $a \mathbf{k}_{\mathbf{m}}$, and $\mathbf{V}_{\max }$ for the enzyme was $0.031 \mathrm{M}$ and 454 $\mathrm{U} / \mathrm{mL}$ ( Fig.6).

\section{Cytotoxicity}

Toxicity is associated with $L$ Glutaminase activity in most L-asparaginases, resulting in the prolonged consumption of L-glutamine by the normal liver and pancreatic cells, resulting in the rise of liver enzymes and pancreatitis. The antileukemic activity of L-Asparaginase was assayed using RAW 2647 leukemia cell line using MTT viability assay. The enzyme recorded significant antileukemic activity against the used cell line. The activity was concentration-dependent. The $\mathrm{IC}_{50}$ was found to be $70 \mathrm{U} / \mathrm{ml}$.

\section{Discussion}

Purification steps resulted in the appearance of one peak of activity. Molecular mass determination using SDS-PAGE revealed the presence of one protein band, indicated total homogeneity of L-Asparaginase. The molecular mass of the enzyme was $22.5 \mathrm{KDa}$ (Fig. 1)

In this respect, different molecular masses of L-Asparaginase were recorded in E. coli (22 kDa)(Narta et al. 2007), Thermus thermophilus (33 kDa) (Pritsa and Kyriakidis 2001), Helicobacter pylori (37 kDa) (Cappelletti et al. 2008) Withania somnifera (36 kDa) (Oza et al. 2010), Erwinia Carnivora (40 kDa) (Koerholz et al. 2009), and Saccharomyces cerevisiae (85 kDa) (Amena et al. 2010). While The highest for Pseudomonas otitidis with a $205 \pm 3 \mathrm{kDa}$ molecular weight(Husain et al. 2015). 
Complete Characterization of the L-Asparaginase was carried out. The enzyme was metalloprotease wholly inhibited by EDTA, $\mathrm{Hg}^{2+}, \mathrm{Cd}^{2+}$, and $\mathrm{Pb}^{2+} . \mathrm{Zn}^{2+}, \mathrm{Mg}^{2+}$, and $\mathrm{Ca}^{2+}$ activated the enzyme. The optimum temperature was $30^{\circ} \mathrm{C}$, optimum pH was 7 (Fig. 2). different ions have different impacts on LAsparaginase activity. Bacillus subtilis B11-06 L-Asparaginase activity was strongly inhibited by $\mathrm{Fe}^{+}$. The presence of $\mathrm{Mn2}^{+}, \mathrm{Zn2}^{+}, \mathrm{Ca}^{+}$, and

$\mathrm{Mg}^{+}$declined rhizobium etli L-Asparaginase activity (Moreno-Enriquez et al. 2012). In the presence of $\mathrm{Cu}^{+}, \mathrm{Cd}^{+}$, and $\mathrm{Hg}^{+}$complete inhibition of I-Asparaginase activity, P. carotovorum MTCC 1428 was found(Kumar et al., 2011). The addition of EDTA as a metal chelating agent did not influence the activity of the enzyme. They proved that the enzyme was not a metalloprotein(Singh and Srivastav 2013; Chohan and Rashid 2013).

L-Asparaginase obtained from most microbial species has an optimum temperature range of $37-40^{\circ} \mathrm{C}$; however, Thermococcus kodaka TK1656 and Thermococcus

gammatolerans $\mathrm{EJ} 3$ at $85^{\circ} \mathrm{C}$ generate thermostable L-Asparaginase(Zuo et al. 2014). Maximum LAsparaginase activity was at $35^{\circ} \mathrm{C}$ at pH $5, \mathrm{KH}_{2} \mathrm{PO}_{4}(0.25 \%), \mathrm{Mg}^{2+}(0.002 \%)$ and sucrose (1\%)(Ruma et al. 2017) .(Sarquis et al. 2004b) reported that $30^{\circ} \mathrm{C}$ was the optimum temperature for L-Asparaginase induction for Aspergillus terreus and A. tamarii. While (Siddalingeshwara and Lingappa 2011) observed a temperature of $37^{\circ} \mathrm{C}$ was optimum for Aspergillus species' asparaginase activity. (S More 2013) Stated the maximum activity of L-Asparaginase of Mucor hiemalis was $30^{\circ} \mathrm{C}$.

the optimum temperature was $30^{\circ} \mathrm{C}$ for Penicillium sp. (Shrivastava et al., 2012). (Chandrasekhar 2012) showed the maximum activity of L-Asparaginase of Aspergillus species was $\mathrm{pH} 7$.

A research study found the optimum $\mathrm{pH}$ for L-asparaginase production by Fusarium species was 6.2 (Thirunavukkarasu et al., 2011). Also, the optimum pH for L-Asparaginase production in Penicillium species was 6.0 (Lincoln et al., 2019). While the optimum pH for L-Asparaginase production by $F$. oxysporum was 5.0 (Yadav and Sarkar 2014). Interestingly, the optimum pH for asparaginase production by Aspergillus Terreus was 8. (Farag et al. 2015)

Almost all the isolated and purified L-Asparaginases from microbial sources operate in a basic medium with an 8.0 to $10 \mathrm{pH}$. However, the extracted enzyme from E.coli was found to work maxim at PH 6, and Bacillus licheniformis produces L-Asparaginase efficiently in slightly acidic to strongly basic medium conditions $6.0-10 \mathrm{pH}$ (Borah et al. 2012). The kinetic parameters of the enzyme must be defined to understand the rates and specificity of most biological processes, aside from gaining knowledge concerning different properties of the enzyme during a biochemical interaction.

The kinetic parameters of the enzyme must be carefully investigated for different industrial approaches. Such parameters rely on different factors, including $\mathrm{PH}$, microbial origin, temperature, and substrate concentration (Miskovic et al., 2019). Substrate specificity was carried out using gelatin and casein in 
addition to L-asparagine. The enzyme was non-specific could hydrolyze all tested substrates. A-line weaver bulk analysis showed a $\mathbf{k}_{\mathrm{m}}$, and ${ }_{\text {Vmax }}$ for the enzyme was $0.031 \mathrm{M}$ and $454 \mathrm{U} / \mathrm{mL}$ (Fig. 6).

L-Asparaginase isolated of Pichia polymorpha had a Km value of $13.7 \mathrm{M}$ and optimum pH of 6.7 (Foda et al., 1980). On the other hand, L-Asparaginase produced by Candid utilis had Km 7.7 M (Sakamoto et al. 1977). L-Asparaginase from Streptomyces brollosae showed maximum activity at $\mathrm{pH}$ 8.5. The optimum temperature of $37^{\circ} \mathrm{C}$., Km value of $0.021 \mathrm{M}$.; Vmax of $152.6 \mathrm{UmL}-1 \mathrm{~min}^{-1}$ (El-Naggar et al. 2018).

The antileukemic cytotoxicity assay of L-Asparaginase was carried out using RAW 2647 leukemia cell line using MTT viability assay. The enzyme showed significant antileukemic activity. The antileukemic activity was concentration-dependent. The $\mathrm{IC}_{50}$ of the enzyme was $70 \mathrm{U} / \mathrm{ml}$ (Fig. 7).

Vast amounts of L-Asparaginase are needed by lymphatic cells to keep their malignant growth as it lacks L-asparagine synthetase. Healthy cells can synthesize L-asparagine so not affected (Narta et al. 2007). LAsparaginase arrest cell cycle in $G 1$ phase in the leukemia murine cell line (Ueno et al. 1997). The cells of CCRF-CEM showed remarkable apoptotic properties after $24 \mathrm{~h}$ exposure, including cell shrinking, chromatin condensation, and loss of typical nuclear architecture (Prakasham et al. 2010).

For successful clinical studies, L-glutaminase free-L-Asparaginase is highly desirable (Distasio et al., 1982). L-Asparaginase from Pectobacterium carotovarum is known to be an excellent anticancer agent (Kumar et al. 2009). L-glutaminase in L-Asparaginase is the leading cause of various side effects of this antileukemic drug (Manna et al. 1995). L-glutamate and ammonia generate from L-glutamine hydrolysis may also contribute to the toxicity of L-Asparaginase in leukemic patients (Richards and Kilberg 2006).

L-Asparaginase importance not only implemented in healthcare and pharmaceuticals but also food industries. To tackle the concerns caused by the unwanted acrylamide production, a carcinogen in particular foodstuffs, such as potato chips and all rich carbohydrates food(Xu et al. 2016). The exposure of millions of people to these products on a daily basis involves severe risks and critical concerns (Adebo et al., 2017).

Studies confirmed the acrylamide formation caused by a Millard reaction between l-asparagine and carbonyl compounds that take place at high temperatures in food sources rich in carbohydrates. LAsparaginase breaks down asparagine into aspartic acid, and ammonia successfully lowers acrylamide levels in potatoes and various bakery products(Pedreschi et al. 2008).

The processing of such products with pure asparaginase like gingerbread has reduced the amount of free asparagine by nearly $70-75 \%$ and the level of acrylamide in baked products by $50-55 \%$ (Adebo et al. 2017). Despite the potential anti-leukemic activity of L-Asparaginase, it causes certain side effects. Where the administration of L-Asparaginase by leukemic patients causes normal cell lethalness(Narta et al. 2007). The enzyme causes a wide range of symptoms, including edema, pancreatic dysfunction, hepatic disorders, neurological convulsions, fever, and skin rashes. Moola recorded some hypersensitivity 
interactions, mild allergic actions, and anaphylactic shock caused by the administration of asparaginasebased drugs.

L-Asparaginase-induced neurotoxicity appears to be more likely in adolescents, resulting in depression, lassitude, brain fog, blurred vision, and agitation(Battistel et al. 2020; Wardani et al. 2020). It is essential to mention here that the glutaminase effects are supposed to lead to the toxicity of L-Asparaginases. LAsparaginase is highly immunogenic with a short half-life. Furthermore, tumor cells were reported to intracellularly produce l-asparagine, which resists the effects of L-Asparaginase(Battistel et al. 2020). The enzyme is also sensitive to thermal and proteolytic digestion and is sometimes denatured by organic solvent exposure. Recombinant molecular cloning and enzyme genetic engineering perpetual improvements could help us overcome such limitations(Zhang et al. 2004; Batool et al. 2016).

\section{Conclusion}

Fusarium sp. L- asparaginase can be used as a substitute for bacterial L-Asparaginase. It showed potent antileukemic activity and had a low $\mathrm{IC}_{50}$ value. L-Asparaginase retrieved from various sources is very crucial due to its anti-cancer and tumor cells therapeutic effects. Besides pharmaceutical usage, in the food industries, it is used to efficiently delay the production of acrylamide in foodstuffs rich in carbohydrates. L-Asparaginase recovered from diverse microbial sources marginally vary in biochemical and physical features with distinct kinetic parameters.

The alterations in the enzyme's physiochemical and kinetic characteristics have afforded us the possibility to search and characterize this enzyme according to the requirements. Some sources provide the efficient working of L-Asparaginase at $37^{\circ} \mathrm{C}$, the human body's normal temperature. Therefore, $\mathrm{L}$ Asparaginase from such sources could be purified and used in healthcare industries.

While the highly thermostable enzyme version can be used in industrial applications that usually demand high temperatures, although L-Asparaginase has become widely used as an anti-cancer medicine and is used in the food industry, its stability and activity are affected by certain limitations. Therefore, it requires sufficient improvements in the enzyme engineering techniques to generate highly versatile versions of the enzyme at the molecular level.

The outlook of L-Asparaginase studies is designed to enhance L-Asparaginase activity and eliminate glutamine and immunosuppressive complications. For a wide range of industrial applications, highly thermostable enzyme versions are currently being genetically engineered.

Furthermore, L-Asparaginase outputs are usually insufficient low as this enzyme's gene expression rate is shallow. In addition, L-Asparaginase is used in the food industry as an aid for the eradication of carcinogenic acrylamide compounds. It is, therefore, our time to explore and optimize production and purification parameters from new enzyme sources so that more potential and specific L-Asparaginase enzyme production can be developed. 
By better understanding of recombinant technologies such as molecular cloning and genetic engineering, novel enzymes with far less immunogenic consequences, unique functionalities, and better half-life could be designed. Finally, using recent recombinant technology could help increase the net output of this powerful therapeutic enzyme.

\section{Declarations}

Acknowledgment: Non-to be declared

Authors Contributions: Conceptualization, Methodology, analysis and investigation, original draft preparation, review, and editing: S.A.A

Data availability not applicable.

Funding: This work has not received any external work.

\section{Compliance with ethical standards}

Competing interests The authors declare that they have no competing interests.

Ethical approval Not applicable.

Consent to participate Not applicable.

Consent to publish Not applicable.

\section{References}

Adebo OA, Kayitesi E, Adebiyi JA, et al (2017) Mitigation of Acrylamide in Foods: An African Perspective. Acrylic Polymers in Healthcare. https://doi.org/10.5772/intechopen.68982

Alam S, Pranaw K, Tiwari R, Khare SK (2019) Recent Development in the Uses of Asparaginase as Food Enzyme. pp 55-81

Ameen F, AlNadhari S, Al-Homaidan AA (2021) Marine microorganisms as an untapped source of bioactive compounds. Saudi Journal of Biological Sciences 28:224-231.

https://doi.org/10.1016/j.sjbs.2020.09.052

Amena S, Vishalakshi N, Prabhakar M, et al (2010) Production, purification and characterization of Iasparaginase from streptomyces gulbargensis. Brazilian journal of microbiology: [publication of the Brazilian Society for Microbiology] 41:173-8. https://doi.org/10.1590/S1517-838220100001000025 
Batool T, Makky EA, Jalal M, Yusoff MM (2016) A Comprehensive Review on I-Asparaginase and Its Applications. Appl Biochem Biotechnol 178:900-923. https://doi.org/10.1007/s12010-015-1917-3

Battistel A, Rocha B, Santos M, et al (2020) Allergic reactions to asparaginase: Retrospective cohort study in pediatric patients with acute lymphoid leukemia. Hematology, Transfusion and Cell Therapy 43:. https://doi.org/10.1016/j.htct.2019.10.007

Borah D, Yadav R, Sangra A, et al (2012) PRODUCTION, PURIFICATION AND PROCESS OPTIMIZATION OF ASPARAGINES. International Journal of Pharmacy and Pharmaceutical Sciences 4:560-563

Cachumba JJM, Antunes FAF, Peres GFD, et al (2016) Current applications and different approaches for microbial l-asparaginase production. Brazilian journal of microbiology: [publication of the Brazilian Society for Microbiology] 47 Suppl 1:77-85. https://doi.org/10.1016/j.bjm.2016.10.004

Cappelletti D, Chiarelli LR, Pasquetto MV, et al (2008) Helicobacter pyloril-asparaginase: A promising chemotherapeutic agent. Biochemical and Biophysical Research Communications 377:1222-1226. https://doi.org/10.1016/j.bbrc.2008.10.118

Chandrasekhar PA (2012) International journal of research in chemistry and environment an international peer reviewed quarterly e-journal; (IJRCE). International Journal of Research in Chemistry and Environment (IJRCE)

Chohan SM, Rashid N (2013) TK1656, a thermostable I-asparaginase from Thermococcus kodakaraensis, exhibiting highest ever reported enzyme activity. J Biosci Bioeng 116:438-443. https://doi.org/10.1016/j.jbiosc.2013.04.005

Costa IM, Schultz L, de Araujo Bianchi Pedra B, et al (2016) Recombinant L-asparaginase 1 from Saccharomyces cerevisiae: an allosteric enzyme with antineoplastic activity. Scientific reports 6:36239. https://doi.org/10.1038/srep36239

Covini D, Tardito S, Bussolati O, et al (2012) Expanding targets for a metabolic therapy of cancer: Lasparaginase. Recent patents on anti-cancer drug discovery 7:4-13

Distasio JA, Salazar AM, Nadji M, Durden DL (1982) Glutaminase-free asparaginase fromvibrio succinogenes: An antilymphoma enzyme lacking hepatotoxicity. International Journal of Cancer 30:343347. https://doi.org/10.1002/ijc.2910300314

Duval M, Suciu S, Ferster A, et al (2002) Comparison of Escherichia coli-asparaginase withErwiniaasparaginase in the treatment of childhood lymphoid malignancies: results of a randomized European Organisation for Research and Treatment of Cancer-Children's Leukemia Group phase 3 trial. Blood 99:2734-2739. https://doi.org/10.1182/blood.V99.8.2734

El-Nagga NE-A, El-Ewasy SM, El-Shweihy NM (2014) Microbial L-asparaginase as a Potential Therapeutic Agent for the Treatment of Acute Lymphoblastic Leukemia: The Pros and Cons. International Journal of 
El-Naggar NE-A, Deraz SF, El-Ewasy SM, Suddek GM (2018) Purification, characterization and immunogenicity assessment of glutaminase free L-asparaginase from Streptomyces brollosae NEAE115. BMC Pharmacology and Toxicology 19:51. https://doi.org/10.1186/s40360-018-0242-1

Farag AM, Hassan SW, Beltagy EA, El-Shenawy MA (2015) Optimization of production of anti-tumor Iasparaginase by free and immobilized marine Aspergillus terreus. Egyptian Journal of Aquatic Research 41:295-302. https://doi.org/10.1016/j.ejar.2015.10.002

Gupta N, Dash S, Basak U (2009) L- asparaginases from fungi of Bhitarkanika mangrove ecosystem. Aspac J Mol Biol Biotechnol 17:

Husain I, Sharma A, Kumar S, Malik F (2015) Purification and characterization of glutaminase free asparaginase from Pseudomonas otitidis: Induce apoptosisin human leukemia MOLT-4 cells. Biochimie 121:. https://doi.org/10.1016/j.biochi.2015.11.012

IMADA A, IGARASI S, NAKAHAMA K, ISONO M (2009) Asparaginase and Glutaminase Activities of Microorganisms. Journal of General Microbiology 76:85-99. https://doi.org/10.1099/00221287-76-1-85

Koerholz D, Brueck M, Nuernberger W, et al (2009) Chemical and immunological characteristics of four different L-asparaginase preparations. European Journal of Haematology 42:417-424. https://doi.org/10.1111/j.1600-0609.1989.tb01464.x

Kornbrust BA, Stringer MA, Lange NEK, Hendriksen HV (2009) Asparaginase - An Enzyme for Acrylamide Reduction in Food Products. In: Enzymes in Food Technology: Second Edition. Wiley Blackwell, pp 59-87 Kumar S, Pakshirajan K, Venkata Dasu V (2009) Development of medium for enhanced production of glutaminase-free l-asparaginase from Pectobacterium carotovorum MTCC 1428. Applied Microbiology and Biotechnology 84:477-486. https://doi.org/10.1007/s00253-009-1973-0

Kumar S, Venkata Dasu V, Pakshirajan K (2011) Purification and characterization of glutaminase-free Lasparaginase from Pectobacterium carotovorum MTCC 1428. Bioresour Technol 102:2077-2082. https://doi.org/10.1016/j.biortech.2010.07.114

LAEMMLI UK (1970) Cleavage of Structural Proteins during the Assembly of the Head of Bacteriophage T4. Nature 227:680-685. https://doi.org/10.1038/227680a0

Lincoln L, Niyonzima F, More S (2019) Purification and Properties of a Fungal L-Asparaginase From Trichoderma Viride Pers: Sf Grey. Journal of Microbiology, Biotechnology and Food Sciences 9:310-316. https://doi.org/10.15414/jmbfs.2014.4.4.310-316

Lopes AM, Oliveira-Nascimento L de, Ribeiro A, et al (2017) Therapeutic I -asparaginase: upstream, downstream and beyond. Critical Reviews in Biotechnology 37:82-99. 
Luhana K, Dave A, Patel K (2013) Production, purification and characterization of extracellular Lasparaginase (Anti Cancerous Enzyme) from Aspergillus Niger. International Journal of Chemtech Applicaions 2:14-25

Manna S, Sinha A, Sadhukhan R, Chakrabarty SL (1995) Purification, characterization and antitumor activity of I-asparaginase isolated from Pseudomonas stutzeri MB-405. Current Microbiology 30:291298. https://doi.org/10.1007/BF00295504

Mashburn LT, Wriston JC (1964) Tumor inhibitory effect of I-asparaginase from Escherichia coli. Archives of Biochemistry and Biophysics 105:450-453

Miskovic L, Tokic M, Savoglidis G, Hatzimanikatis V (2019) Control Theory Concepts for Modeling Uncertainty in Enzyme Kinetics of Biochemical Networks. Ind Eng Chem Res 58:13544-13554. https://doi.org/10.1021/acs.iecr.9b00818

Moreno-Enriquez A, Evangelista-Martinez Z, Gonzalez-Mondragon EG, et al (2012) Biochemical characterization of recombinant $L$-asparaginase (AnsA) from Rhizobium etli, a member of an increasing rhizobial-type family of L-asparaginases. J Microbiol Biotechnol 22:292-300.

https://doi.org/10.4014/jmb.1107.07047

M.Sc AS, Khan AA, Shrivastav A, et al (2012) KINETIC STUDIES OF L-ASPARAGINASE FROM Penicillium digitatum. Preparative Biochemistry \& Biotechnology 42:574-581.

https://doi.org/10.1080/10826068.2012.672943

Narta UK, Kanwar SS, Azmi W (2007) Pharmacological and clinical evaluation of I-asparaginase in the treatment of leukemia. Critical Reviews in Oncology/Hematology 61:208-221.

https://doi.org/10.1016/j.critrevonc.2006.07.009

Orabi H, El-Fakharany E, Abdelkhalek E, Sidkey N (2019a) L-Asparaginase and L-glutaminase: Sources, production, and applications in medicine and industry. Journal of Microbiology, Biotechnology and Food Sciences 9:. https://doi.org/10.15414/jmbfs.2019.9.2.179-190

Orabi HM, El-Fakharany EM, Abdelkhalek ES, Sidkey NM (2019b) L-Asparaginase and L-glutaminase: Sources, production, and applications in medicine and industry. Journal of Microbiology, Biotechnology and Food Sciences 179-190. https://doi.org/10.15414/jmbfs.2019.9.2.179-190

Oza VP, Parmar PP, Kumar S, Subramanian RB (2010) Anticancer Properties of Highly Purified IAsparaginase from Withania somnifera L. against Acute Lymphoblastic Leukemia. Applied Biochemistry and Biotechnology 160:1833-1840. https://doi.org/10.1007/s12010-009-8667-z

Pedreschi F, Kaack K, Granby K (2008) The effect of asparaginase on acrylamide formation in French fries. Food Chemistry 109:386-392. https://doi.org/10.1016/j.foodchem.2007.12.057 
Pieters R, Hunger SP, Boos J, et al (2011) L-asparaginase treatment in acute lymphoblastic leukemia. Cancer 117:238-249. https://doi.org/10.1002/cncr.25489

Prakasham RS, Hymavathi M, Subba Rao C, et al (2010) Evaluation of Antineoplastic Activity of Extracellular Asparaginase Produced by Isolated Bacillus circulans. Applied Biochemistry and Biotechnology 160:72-80. https://doi.org/10.1007/s12010-009-8679-8

Pritsa AA, Kyriakidis DA (2001) L-asparaginase of Thermus thermophilus: Purification, properties and identificaation of essential amino acids for its catalytic activity. Molecular and Cellular Biochemistry 216:93-101. https://doi.org/10.1023/A:1011066129771

Richards NGJ, Kilberg MS (2006) Asparagine Synthetase Chemotherapy. Annual Review of Biochemistry 75:629-654. https://doi.org/10.1146/annurev.biochem.75.103004.142520

Ruma K, George TK, Aswani P, Jisha MS (2017) Production and Optimization of Extra Cellular Lasparaginase by Fusarium solani Isolated from Withania sominifera. Journal of Biologically Active Products from Nature 7:81-88. https://doi.org/10.1080/22311866.2017.1325007

S More S (2013) Isolation, Purification and Characterization of Fungal Extracellular L-Asparaginase from Mucor hiemalis. Journal of Biocatalysis \& Biotransformation 02: https://doi.org/10.4172/23249099.1000108

Sakamoto T, Araki C, Beppu T, Arima K (1977) Extracellular Asparaginase from Candida utilis, Its Properties as Glycoprotein and Antitumor Activities. Agricultural and Biological Chemistry 41:1365-1371. https://doi.org/10.1080/00021369.1977.10862699

Sarquis MI de M, Oliveira EMM, Santos AS, Costa GL da (2004a) Production of L-asparaginase by filamentous fungi. Mem Inst Oswaldo Cruz 99:489-492. https://doi.org/10.1590/s007402762004000500005

Sarquis MI de M, Oliveira EMM, Santos AS, Costa GL da (2004b) Production of L-asparaginase by filamentous fungi. Memórias do Instituto Oswaldo Cruz 99:489-492. https://doi.org/10.1590/S007402762004000500005

Shrivastava A, Khan AA, Shrivastav A, et al (2012) Kinetic studies of L-asparaginase from Penicillium digitatum. Preparative biochemistry \& biotechnology 42:574-581.

https://doi.org/10.1080/10826068.2012.672943

Siddalingeshwara KG, Lingappa K (2011) Production and characterization of Lasparaginase - a tumour inhibitor. International Journal of PharmTech Research 3:314-319

Singh Y, Srivastav SK (2013) Statistical and evolutionary optimization for enhanced production of an antileukemic enzyme, L-asparaginase, in a protease-deficient Bacillus aryabhattai ITBHU02 isolated from the soil contaminated with hospital waste. Indian J Exp Biol 51:322-335 
Taubeneck U (2007) J. R. NORRIS and D. W. RIBBONS (Editors), Methods in Microbiology, Vols. 4-7. Vol. 4: 795 S., $£$ 11.00; Vol. 5A: 450 S., $£$ 7.75; Vol. 5B: 695 S., $£$ 9.50; Vol. 6A: 593 S., $£$ 9.00; Vol. 6B: 385 S., $£$ 7.00; Vol. 7A: 479 S., $£$ 8.50; Vol. 7B: 388 S., $£$ 7.00. Za. Zeitschrift für allgemeine Mikrobiologie 14:261261. https://doi.org/10.1002/jobm.19740140317

Thirunavukkarasu N, Suryanarayanan TS, Murali TS, et al (2011) L-asparaginase from marine derived fungal endophytes of seaweeds. Mycosphere 2:147-155. https://doi.org/10.1111/j.1365313X.2009.03887.x.zation

Ueno T, Ohtawa K, Mitsui K, et al (1997) Cell cycle arrest and apoptosis of leukemia cells induced by Lasparaginase. Leukemia 11:1858-61

Wardani NMS, Osseva N, Suryawan N (2020) ALLERGIC REACTION TO ESCHERICHIA COLIASPARAGINASE IN CHILDHOOD ACUTE LYMPHOBLASTIC LEUKEMIA: A STUDY IN A TERTIARY HOSPITAL IN INDONESIA. Asian Journal of Pharmaceutical and Clinical Research 13:142-146. https://doi.org/10.22159/ajpcr.2020.v13i4.36807

Xu F, Oruna-Concha M, Elmore J (2016) The use of asparaginase to reduce acrylamide levels in cooked food. Food Chemistry 210:163-171. https://doi.org/10.1016/j.foodchem.2016.04.105

Yadav N, Sarkar S (2014) Production of L-Asparaginase By Fusarium Oxysporum Using Submerged Fermentation. International Journal of Pharmaceutical Science Invention 3:32-40

Zhang J-F, Shi L-Y, Wei D-Z (2004) Chemical modification of L-asparaginase from Escherichia coli with a modified polyethyleneglycol under substrate protection conditions. Biotechnol Lett 26:753-756. https://doi.org/10.1023/b:bile.0000024100.49716.3d

Zuo S, Xue D, Zhang T, et al (2014) Biochemical characterization of an extremely thermostable Lasparaginase from Thermococcus gammatolerans EJ3. Journal of Molecular Catalysis B: Enzymatic 109:. https://doi.org/10.1016/j.molcatb.2014.08.021

\section{Figures}




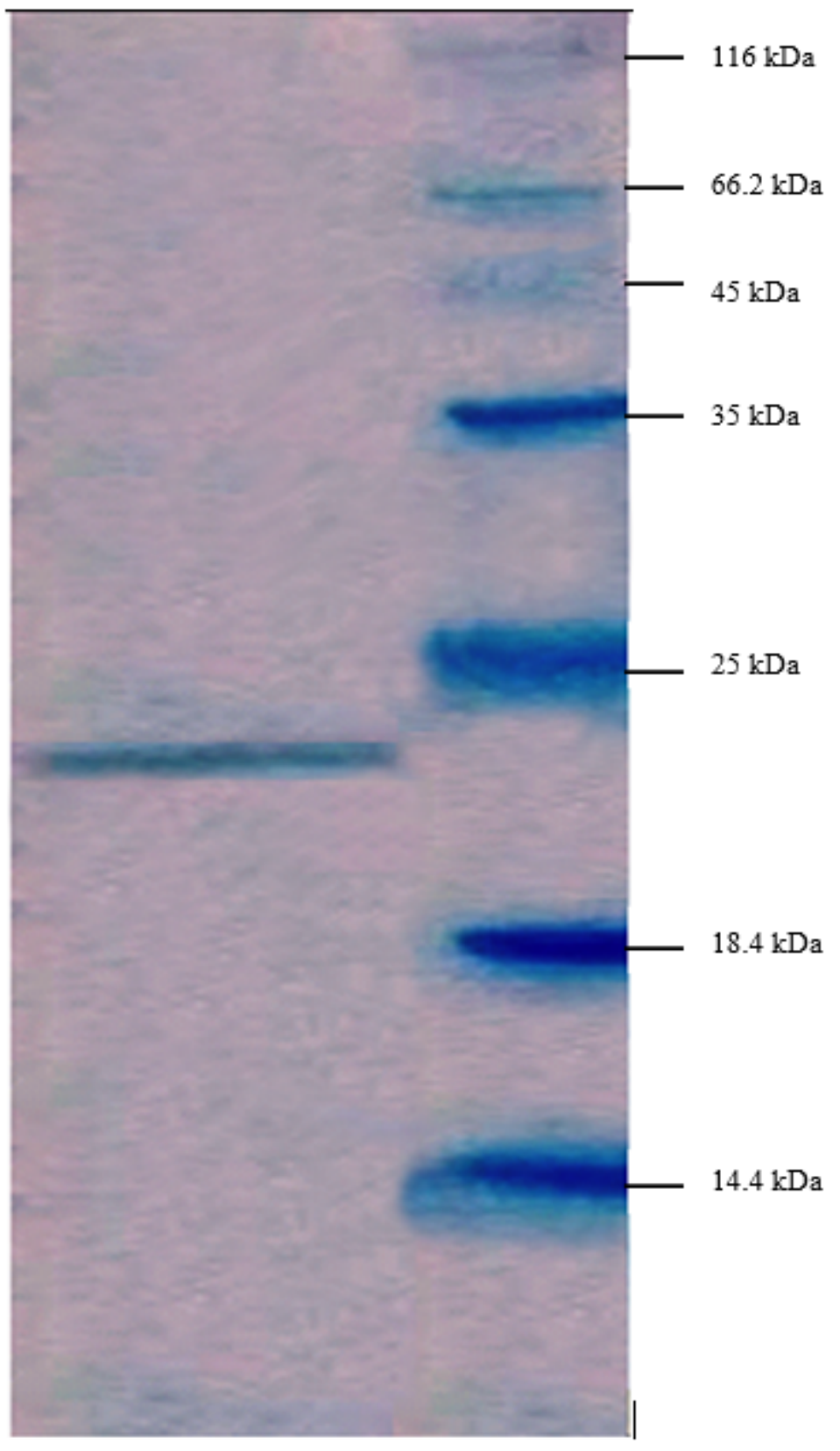

Figure 1

Molecular mass of the purified L- asparaginase 


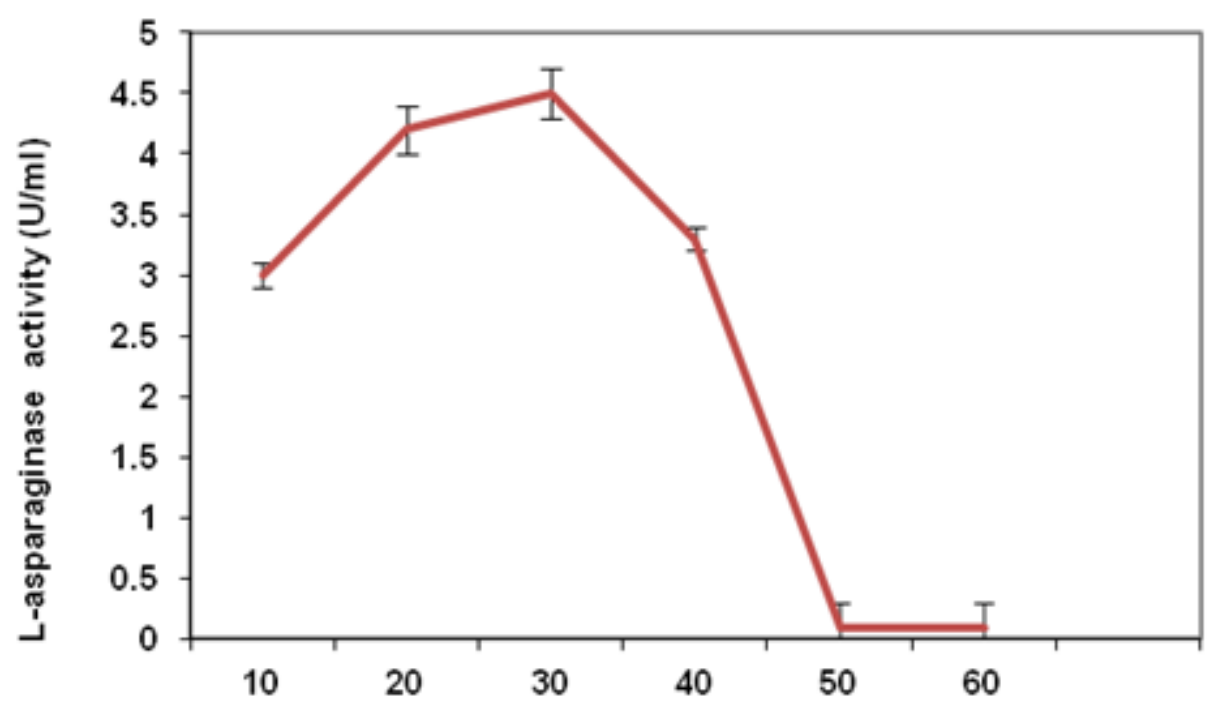

Figure 2

Effect of temperature on L-Asparaginase activity

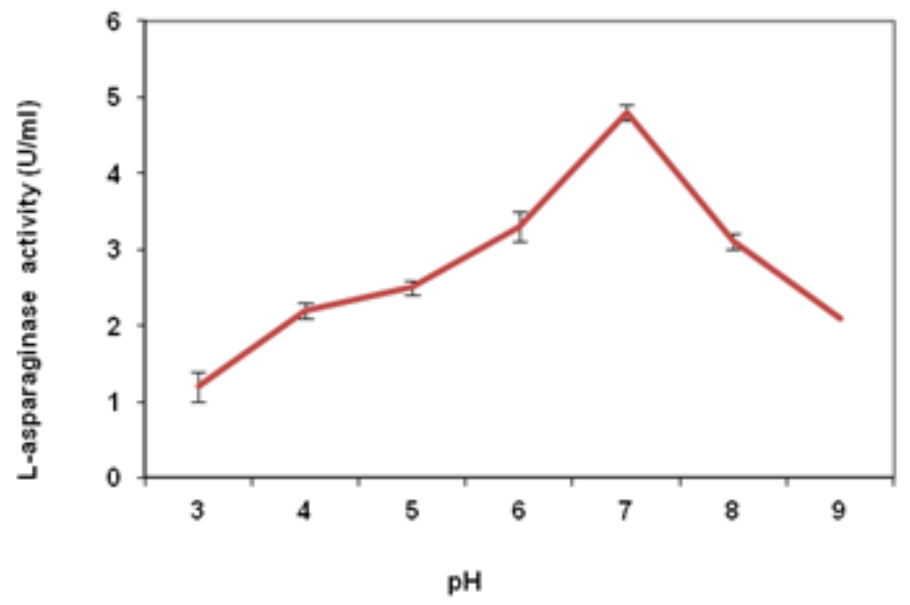

Figure 3

Effect of PH on L-Asparaginase activity 


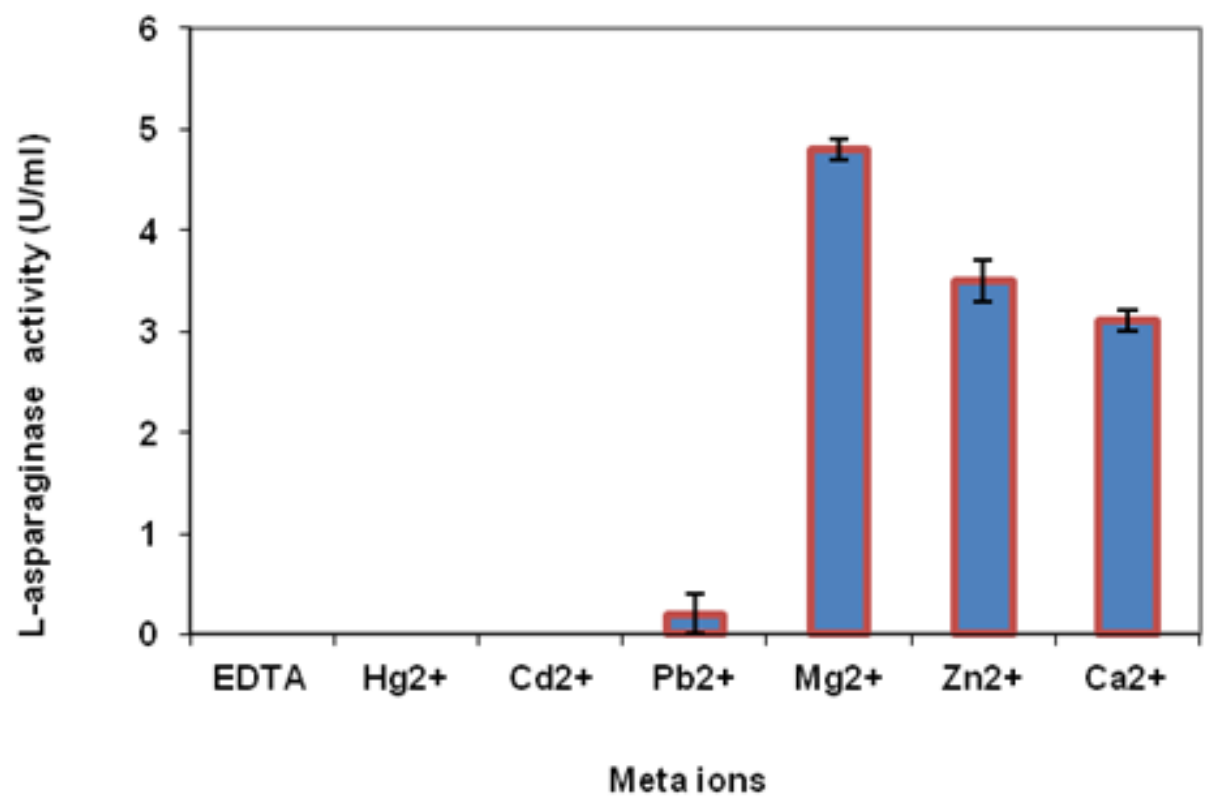

Figure 4

Activation and inhibition of some metal ions on L-Asparaginase

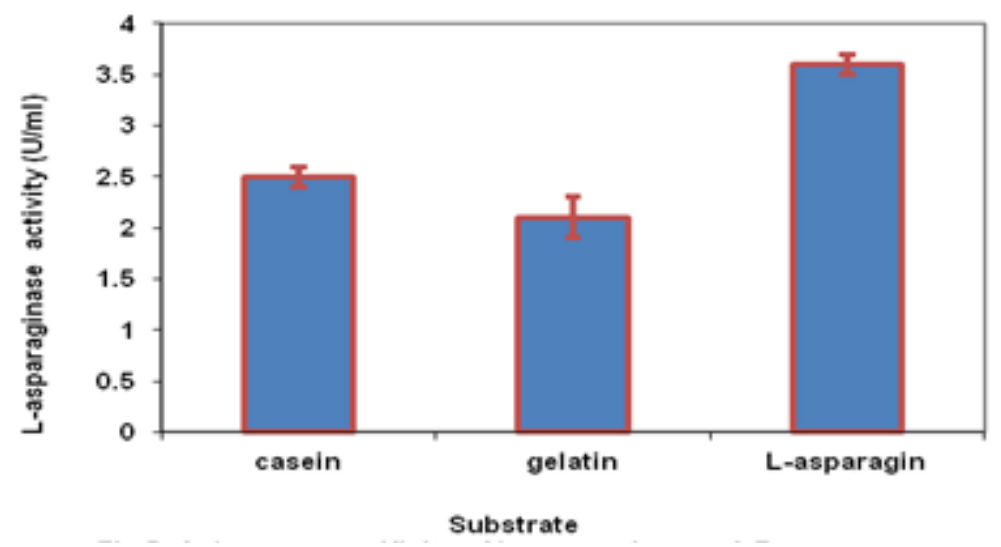

Figure 5

Maximum enzyme activity was recorded in the case of L-asparagine. 


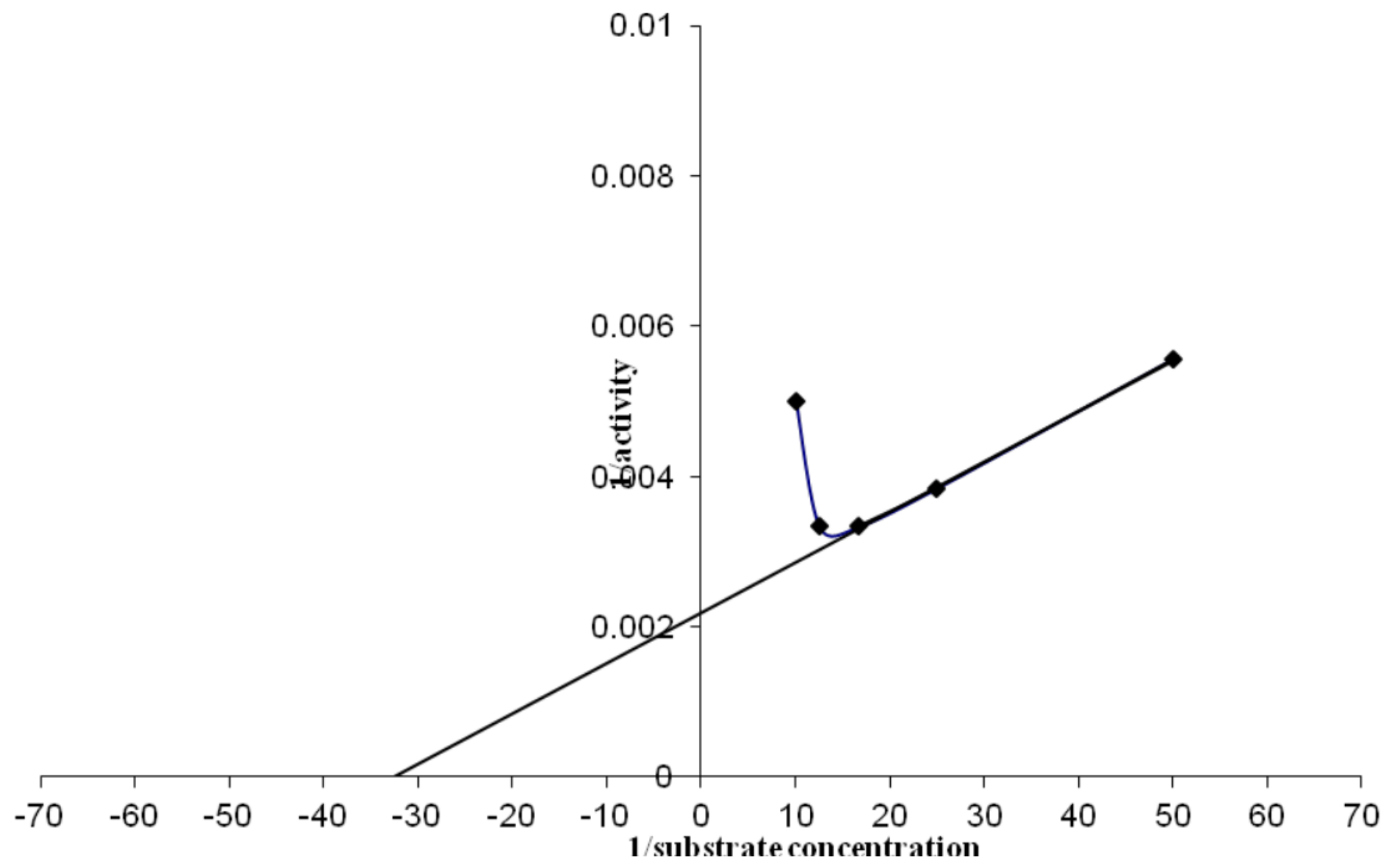

Figure 6

$\mathrm{Km}$ and $\mathrm{Vmax}$ of L-asparginase

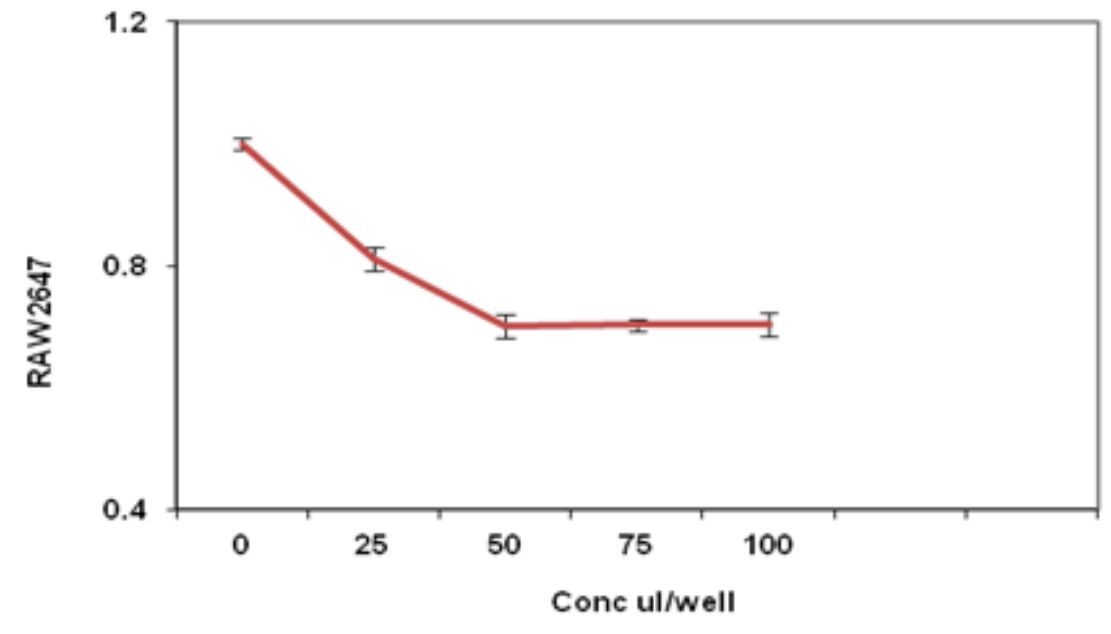

Figure 7

Antileukemic activity of L-Asparaginase 